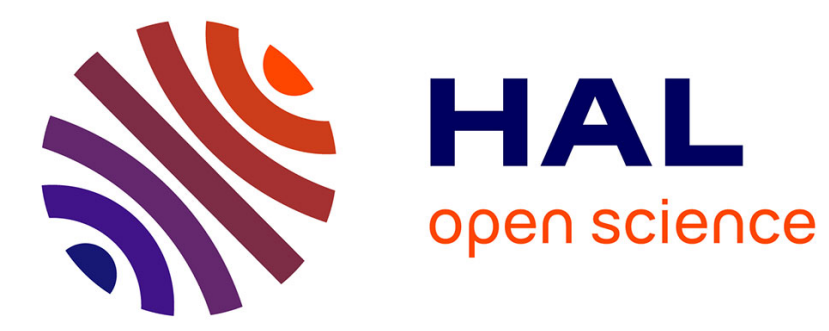

\title{
Trade, demand spillovers and industrialization: The emerging global middle class in perspective
}

Alain Desdoigts, Fernando Jaramillo

\section{To cite this version:}

Alain Desdoigts, Fernando Jaramillo. Trade, demand spillovers and industrialization: The emerging global middle class in perspective. 2009. halshs-00111186v3

\section{HAL Id: halshs-00111186 \\ https://shs.hal.science/halshs-00111186v3}

Submitted on 24 Sep 2009

HAL is a multi-disciplinary open access archive for the deposit and dissemination of scientific research documents, whether they are published or not. The documents may come from teaching and research institutions in France or abroad, or from public or private research centers.
L'archive ouverte pluridisciplinaire HAL, est destinée au dépôt et à la diffusion de documents scientifiques de niveau recherche, publiés ou non, émanant des établissements d'enseignement et de recherche français ou étrangers, des laboratoires publics ou privés. 


\section{Centre d'Economie de la Sorbonne}

Trade, demand spillovers and industrialization :

The emerging global middle class in perspective

Alain DesDoigts

Fernando JARAMILLO

2006.14

Version finale
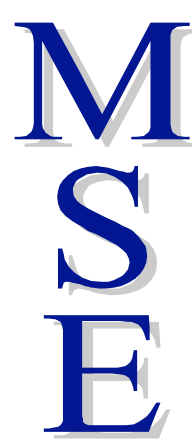

la

de

CENTRE NATIONAL

DE LARECHERCHE

SCENTIFIQUE 


\title{
Trade, demand spillovers, and industrialization: The emerging global middle class in perspective.
}

\author{
Alain Desdoigts ${ }^{\dagger}$ and Fernando Jaramillo ${ }^{\ddagger}$
}

\begin{abstract}
May 2009)
In this paper, we investigate international demand spillovers brought about by a global middle class and their impact on trade patterns and industrialization. We propose a multi-industry and two-country trade model featuring demand complementarities propagating increasing returns across industries and national boundaries. We show how the international extent of demand spillovers depends upon asymmetries in domestic income distribution, labor efficiency, and labor force size; that is, on the global distribution of real income.
\end{abstract}

Keywords: Trade, Spillovers, Nonhomothetic preferences, World income distribution

JEL classification: F10, O11, O14

\footnotetext{
${ }^{0}$ We thank Micael Castanheira, Simon Gilchrist, Paolo Guarda, Fabien Moizeau, JeanPhilippe Tropeano, and Thierry Verdier for their comments and suggestions. The present version owes much to thoughtful comments by anonymous referees. The paper also benefited from the feedback of the Editor and seminar participants at Crest-Insee (Paris), ECARES (Bruxelles), GREMAQ (Toulouse), the Workshop in Development Economics (Louvain-La-Neuve 2005), the University of Warwick, and the Final Conference of the RTN "Trade, Industrialisation and Development" (CEPR, Paris 2006). Fernando Jaramillo acknowledges the hospitality of Université Paris 1 Panthéon-Sorbonne and Université ParisEst and funding from the Centre National de la Recherche Scientifique (CNRS). The standard disclaimer applies.

† Université Paris-Est and Paris School of Economics, Centre d'Economie de la Sorbonne, 106/112 Bd de l'Hôpital, 75647 Paris 13 cedex - France. adesdoigts@free.fr.

$\ddagger$ Universidad del Rosario, Calle 14 \# 4-69, Bogotá - Colombia. fernando.jaramillo71@urosario.edu.co.
} 


\section{Introduction}

Brazil, Russia, India and China (BRIC) form the core of an emerging global middle class. In this paper, we investigate how a global middle class may influence trade flows of goods and services and the pattern of global production. We focus on international demand spillovers which contribute to expand production and achieve increasing returns to scale. Much as technical externalities propagate increasing returns across industries and national borders, global demand spillovers may also generate such effects. There are potential benefits to the world economy from the emergence of a large number of consumers whose tastes will change as their living standards catch up with those in advanced nations. According to the World Bank, the emergence of a global middle class will cause a major change in the demand for goods, creating huge markets ${ }^{1}$. A new age of mass consumption is likely to accompany the next wave of globalization.

Conversely, the emergence of BRIC countries on the international economic scene poses a challenge to both advanced nations and smaller emerging countries. If China's economic performance is in line with the Japanese integration experience, the size of the former will have a particularly important impact on the modernization or decline of industrial activities across regions of the globe (see Winters and Yusuf 2007). Competition spans increasingly diversified activities. The sheer size of these newcomers means that these spillover effects may dwarf the comparison with either Japan or South Korea.

On the one hand, trade theory traditionally concentrates on the supply side. One standard assumption is that preferences are identical across trade partners and homothetic, i.e., as income increases, consumption of each good increases proportionately. As a result, demand-side effects are neutralized as

\footnotetext{
${ }^{1}$ Their last projections are eloquent (see Global Economic Prospects 2007, Chapter 3, p. 69):
}

"In 2030, 16.1 percent of the world population will belong to what can be called a 'global middle class' up from 7.6 percent in 2000. That is, in 2030 more than a billion people in developing countries will buy cars, engage in international tourism, demand world-class products... Compare that with only 400 million people in developing countries who had access to these kinds of living standards in $2005 \ldots$ This large middle class will create rapidly growing markets for international products and services..." 
a determinant of the composition of trade. This is in contradiction to the stylized facts. In reality, differences in purchasing power lead different goods to be consumed (see, among others, Francois and Kaplan 1996 and Dalgin, Mitra, and Trindade 2004).

On the other hand, there is a long tradition in development economics, going back to the parable of the shoe factory by Rosentein-Rodan (1943), that emphasizes how a positive sectoral shock may stimulate the development of other sectors through market-size externalities linked to increasing returns to scale. However, it was not until the end of the Eighties that Rosentein-Rodan's arguments describing economic development as a virtuous circle driven by external economies, were formalized by Murphy et al. in two companion papers $(1989 a, b)$. In the first paper, they model the socalled 'big push' which produces industrial modernization as the outcome of coordinated investments which propagate increasing returns across industries. In the second paper (henceforth MSV), pecuniary externalities work via the buying power of the middle class to eventually determine the extent of horizontal complementarity across all industries of the economy. In the words of Matsuyama (1995, p. 703):

"... Suppose the [middle class] increases its demand for monopolistically competitive goods... Because prices exceed marginal costs, such a shift in demand would increase the level of monopoly profits in the economy and thus national income. This increased income would generate additional demand for monopolistically competitive goods, which further raises profits and income and so on..."

This kind of argument which captures how 'one thing leads to another', does not generalize directly to an integrated world economy. Our contribution focuses on such a form of complementarity and allows domestic demand to potentially spill over to any rival foreign industry, giving rise to a global profit-multiplier process. In MSV, such a multiplier is limited to the home market and determined only by the size of the domestic middle class. We extend their closed-economy general equilibrium model to a two-country framework where goods produced in both countries are substitutes and differentiated by their country of origin. According to the relative size of the domestic markets and the competitiveness of home and foreign rival firms, each product may be produced domestically under internal increasing returns 
by a monopolist or by a competitive fringe under constant returns to scale. Eventually, the magnitude and direction of international demand spillovers determine the strength of increasing returns and as a result, the importance of the cumulative processes in each country ${ }^{2}$.

The market size for each good depends on the number of agents that can purchase it, which itself depends on the distribution of purchasing power both across and within trade partners. Under free trade, the domestic middle class is a relative notion which is not internationally comparable. A middle class household in its own country may be rich enough to belong to the upper class of the world income distribution. Conversely, a household may be rich by national standards but belong to the global middle class. In a closed economy, all profits and wages distributed to the domestic middle class return as demand addressed to the home industries. By opening to trade, they become a component of demand for either the home good or the substitute produced abroad, depending on the level of international competitiveness. This, in turn, affects real national incomes and welfare. Thus international trade leads the global middle class purchasing power to interact with increasing returns making them stronger or weaker depending upon asymmetries in domestic income distribution, labor efficiency, and labor force size.

First, we show that export-competing industries in the unequal country can take advantage of the larger middle class in the more egalitarian trade partner, so that trade integration tends to equalize average income of trade partners who differ only in their income distribution.

Secondly, when trade partners differ only in their labor efficiency, free trade exacerbates international disparities in real average income and makes increasing returns weaker in the technically backward country which might be tempted to revert to autarky. This dampens the local market-size externalities' argument by MSV and revives the argument for protection. The intuition behind this pattern is easy to grasp. First, terms of trade must adjust to reflect labor efficiency differences, penalizing the ability of firms in the lagging country to compete in the global market. Secondly, the top-middle class of the lagging country becomes the bottom-middle class in the global

\footnotetext{
${ }^{2}$ Incidentally, MSV acknowledge that (p. 560): "This question gains particular significance in the open economy, where foreign competition might reduce [industrial modernization]... We have only focused on the income distribution as the determinant of market size. One can also consider other important determinants of market size, such as population size and average income, and ask various questions about industrialization in small versus large countries, as well as in poor versus rich countries."
} 
context. A large proportion of its consumers becomes a source of increasing returns in the advanced country, boosting production in the area of goods with lower income elasticities of demand. In the lagging country, the higher advanced country's middle class purchasing power benefits sectors producing goods with relatively higher income elasticities of demand and mostly subject to constant returns to scale. Examples we have in mind concern the toy industry in China and tourism.

Thirdly, we explore how worldwide demand complementarities influence trade patterns and industrialization between countries differing only in the size of their labor force. We show that trade integration favors the small economy because international demand spillovers lead the large country's middle class buying power to strengthen increasing returns in the small trade partner's industries.

Finally, we investigate the consequences of a technically backward trade partner narrowing its technological gap under the free trade regime, as well as trade between a large emerging country and a smaller industrialized country. Technological catch-up yields a decline in export prices in the emerging country's firms which become relatively more competitive. A larger variety of goods is produced under increasing returns because of the increased buying power of the emerging global middle class, brought about by lower prices. Eventually, demand complementarities propagate increasing returns across national boundaries, so that the rise in average productivity in the emerging country spills over to those industries in the advanced country which produce goods with high income elasticities of demand.

To our knowledge, the papers most closely related to our study are those by Matsuyama (2000) and Mitra and Trindade (2005). Matsuyama incorporates international demand complementarities in a Ricardian model à la Dornbusch et al. (1977), i.e., with a continuum of industries. The assumed pattern of comparative advantage leads the technological leader to completely specialize in goods with higher income elasticities of demand, whereas the developing country exports more basic goods. Matsuyama then discusses the impact of market size and technology differences on trade flows. However, by adopting a Ricardian framework, he considers neither international competition nor demand complementarities as a source of increasing returns. The same limitation applies to Mitra and Trindade's contribution. They adopt a $2 \times 2$ Heckscher-Ohlin framework where trade partners are identical in every respect except for their income distribution. With homothetic preferences, this means that a move from autarky to free trade has no consequence on 
either trade partners. With non-homothetic preferences though, the more unequal (equal) country has a higher demand for labor- (capital-) intensive good which, by assumption, is characterized by a lower (higher) income elasticity of demand. This yields 'specialization in consumption, not production'.

One implication of increasing returns to scale for international trade is the possibility of losses from trade for one country therefore justifying protection. This argument was introduced into the trade literature by Graham (1923), and formalized by Ethier (1982) in a two-country (alike in every respect except for size), two-sector model in which one is subject to increasing returns and the other to constant returns to scale. Our paper is also related to that strand of the literature which deals with increasing returns and gains from trade as covered by Helpman (1984) and Helpman and Krugman (1985). It examines the impact of demand for the goods produced under increasing returns on gains from trade, by combining internal increasing returns and trade in differentiated goods. Note first that this rules out perfect competition and thus differs from Ethier's setting which considers trade in homogeneous goods and external increasing returns to scale. Secondly, in contrast to the trade literature dealing with differentiated goods under monopolistic competition and the home market effect of Krugman (1980), there will be no trade-off between increasing returns and the number of varieties produced by the domestic industry. Our variable of interest is not the implicit zero-profit number of firms in each industry, but the profits realized in each industry. A larger market for a particular industry is not synonymous with more firms, it rather yields higher profits which translate into a larger multiplier.

Lastly, Hirschman's (1958) concept of backward and forward linkages is very much related to Rosentein-Rodan's (1943) ideas in that it also involves the interaction between market size and increasing returns to scale arising from externalities. Until recently, their arguments suffered from a lack of interest by the profession (see Krugman 1995). In this respect, it is worth pointing out another line of research pioneered by Rodríguez-Clare (1996) who offers a formal treatment in a two-country model of Hirschman's linkages by focusing on their generation by multinationals.

The paper proceeds as follows. Section 2 presents the model. Section 3 describes the world general equilibrium under free trade. Our main results are derived in Section 4, where we analyze the impact of asymmetries in, successively, (i) income inequality, (ii) labor efficiency, and (iii) labor force size on the global industrial activity and trade patterns. Finally, in Section 
5, we investigate the impact of a change in labor efficiency, extending our analysis to free trade between an industrialized country and a larger emerging country, e.g., US versus China. Section 6 concludes.

\section{The model}

Our model is a two-country framework, 1 and 2, where subscripts $i$ and $j$ are used as non specific references to 1 and $2(\{i, j\}=\{1,2\})$. When two subscripts are attached to a variable, the former identifies the country of origin of the good while the latter denotes the country in which it is consumed.

\subsection{Preferences}

Households are heterogeneous with respect to the utility they incur from buying the domestic or foreign variety of a given good. We follow the ideal product approach (see Lancaster 1979) and attach a value $m_{i}$ to each household which measures the utility from purchasing a good produced in country $i$. It is assumed that $m_{1}=m$ is a random variable from a uniform distribution on the interval $(0,1]$ and $m_{2}=1-m$.

We define a utility function of a type- $m$ household over an infinite continuous range of indivisible goods $q \in(0, \infty)$, by

$$
V^{m}=\int_{0}^{\infty}(1+q)^{-\sigma}\left(m_{i}^{\delta} X_{i}^{q}+\left(1-m_{i}\right)^{\delta} X_{j}^{q}\right) d q, i, j=1,2 \text { and } i \neq j,
$$

where $X_{i}^{q}+X_{j}^{q} \leq 1$, and parameters $\delta, \sigma>0$. Each good $q$ is differentiated on the basis of the country of origin.

Let $X_{i}^{q}$ be an indicator function which takes the form

$$
X_{i}^{q}=\left\{\begin{array}{c}
1 \text { if the household buys country } i \text { 's variety of good } q \\
0 \text { otherwise }
\end{array} .\right.
$$

Our preference modelling has a number of implications. First, households must choose their most preferred good or 'ideal product' out of each industry $q$, where at most only two varieties (home and foreign) of each good $q$ may be available in the global market. A single household either buys home or foreign goods but never a combination of the two. Secondly, there is satiability of 
preferences and a household's utility increases with the range of goods $(0, q)$ it consumes and not with the consumption of a single good $q$. Thirdly, the proportion of income that households spend on lower-indexed goods or on goods with lower income elasticities of demand, decreases with a household's income. Hence, richer households can consume more than the bundle of goods available to poorer households.

For a type- $m$ household, the country $i$-product variety of good $q$ is preferred if

$$
\frac{m_{i}^{\delta}}{p_{i}^{q}}>\frac{m_{j}^{\delta}}{p_{j}^{q}} \Leftrightarrow m_{i}>\frac{\left(p_{i}^{q}\right)^{1 / \delta}}{\left(p_{i}^{q}\right)^{1 / \delta}+\left(p_{j}^{q}\right)^{1 / \delta}}, i, j=1,2 \text { and } i \neq j,
$$

where $p_{i}^{q}$ is the price of good $q$ produced in country $i$. On the one hand, suppose $p_{i}^{q}>p_{j}^{q}$ and $\delta=0$, all households are better off by acquiring the cheapest variety. On the other hand, if $\delta$ approaches infinity, the fraction of households purchasing home goods equals one half, irrespective of their price. Thus, $\delta$ measures the relative price sensitivity of demand.

\subsection{Technology}

Human capital is the only input in production and the stock of human capital in country $i$ is equal to $\bar{h}_{i} L_{i}$, where $L_{i}$ is the size of the labor force and $\bar{h}_{i}$ is the average level of human capital. In each country, two technologies are available to produce each variety of good. One technology is assumed to exhibit constant returns to scale (CRS). It requires $\alpha / A_{i}$ units of human capital, with $\alpha>1$, to produce one unit of good $q$. $A_{i}$ acts as an index of productivity of the labor force in country $i$ and differs by a uniform amount across trade partners, i.e., $A_{i}(q) / A_{j}(q), i \neq j$, is identical for all $q$. The alternative technology is characterized by increasing returns to scale (IRS). It requires $1 / A_{i}$ units of human capital to produce one unit of good $q$ plus a fixed setup of $F / A_{i}$ units of human capital. A firm switching from the CRS to the IRS technology is used as a metaphor for industrial modernization. All firms in each country may serve both their domestic and export market.

\subsection{Income inequality and the budget constraint}

Households also differ in terms of their income. Following MSV, we assume that there is an exogenous nondegenerate distribution of assets $G_{j}(\gamma)$ in country $j$ with $\gamma \in\left[\underline{\gamma}_{j}, \infty\right)$ and $\underline{\gamma}_{j} \geq 0$, the minimum share of ownership. Within 
the present framework, $\underline{\gamma}_{j}$ acts as a threshold which must be interpreted as the poverty line above which one finds two categories of households, where each household is a member by country $j$ standards of either the middle or the upper class.

We define a class $\gamma$ of households' income $\left(y_{j}^{\gamma}\right)$ in country $j$ as follows

$$
y_{j}^{\gamma}=\gamma\left(w_{j} \bar{h}_{j} L_{j}+\pi_{j}\right), j=1,2,
$$

where $\pi_{j}$ denotes aggregate profits, $w_{j}$ is the wage per unit of human capital, and $\gamma$ is the extent of ownership of all profit-making firms located in country $j$ held by type- $\gamma$ households.

For analytical convenience, $G_{j}(\gamma)$ is assumed to be perfectly correlated with the distribution of the human capital endowment and a type- $\gamma$ household supplies $\gamma \bar{h}_{j} L_{j}$ units of human capital inelastically. Let $\left(0, q^{\gamma}\right)$ be the bundle of goods purchased by the household with a share in the profits $\gamma$ in country $j$. Since there is preference satiability and goods are indivisible, its budget constraint is given by

$$
\int_{0}^{q^{\gamma}}\left(\sum_{i} p_{i}^{q} X_{i}^{q}\right) d q=\gamma\left(w_{j} \bar{h}_{j} L_{j}+\pi_{j}\right), j=1,2 .
$$

\section{International general equilibrium}

\subsection{Effective demand size and minimum efficient scale}

We begin by restating the MSV's price equilibrium strategy in a closed economy. Each good $q$ may be produced either by a competitive fringe with the CRS technology or by a monopolist with the IRS technology if demand is high enough to cover fixed costs. When it is produced with the CRS technology, the free entry zero-profit condition ensures that the price is equal to average cost, i.e., $p_{i}^{q}=\alpha w_{i} / A_{i}$. Suppose that in each sector in either country, there is only one firm with access to IRS technology. MSV show that under a plausible assumption on $G_{j}(\gamma)$, the unique Nash equilibrium is for domestic monopolists in some subset of sectors $(0, q)$ to enter and to keep prices at $\alpha w_{i} / A_{i}$. They neither cut prices, nor do they benefit from increasing them.

When there is no technology transfer and countries trade freely, we show that the Nash equilibrium price strategy for monopolists in countries 1 and 2 entering the global marketplace is also to keep prices at respectively $\alpha w_{1} / A_{1}$ 
and $\alpha w_{2} / A_{2}$. A sufficient condition is that the world distribution of real income be sufficiently smooth, i.e., 'without large peaks or discrete spikes' (see Appendix for details). A key implication for our model is that trade between countries of different size and/or factor efficiency can be closely related to a standard world price equilibrium along the lines of a Ricardian model.

As long as $L_{i}>F /(\alpha-1)$, we have the following break-even condition: A good $q$ is produced in country $i$ with the IRS technology if the demand for that $\operatorname{good}\left(D_{i}^{q}\right)$ satisfies

$$
\frac{(\alpha-1) w_{i}}{A_{i}} D_{i}^{q}-\frac{F w_{i}}{A_{i}} \geq 0 \Leftrightarrow D_{i}^{q} \geq \frac{F}{\alpha-1}, i=1,2,
$$

with the minimum efficient scale defined by $D_{i}^{*}=F /(\alpha-1)$.

Let $q_{i}^{*}$ denote the good produced at that minimum efficient scale in country $i$. Then, industries which produce lower- (higher-) indexed goods use IRS (CRS) technologies. Thus, $q_{i}^{*}$ measures the variety of goods produced using IRS in country $i$. We define $\gamma_{i j}^{*}$ as the share ownership of the marginal household living in country $j$ and whose purchasing power allows it to buy $\left(0, q_{i}^{*}\right)$ :

$$
q_{i}^{*}=\frac{\gamma_{i j}^{*}\left(w_{j} \bar{h}_{j} L_{j}+\pi_{j}\right)}{p_{i}}=\frac{A_{j}}{\alpha} \frac{p_{j}}{p_{i}} \gamma_{i j}^{*}\left(\bar{h}_{j} L_{j}+\frac{\pi_{j}}{w_{j}}\right), i, j=1,2 .
$$

Country 1's labor force can be divided into: (i) households which have enough buying power to purchase all goods produced under IRS in country 1 $\left(0, q_{1}^{*}\right)$ plus some higher-indexed goods which are produced under CRS, i.e., $\gamma \geq \gamma_{11}^{*}$, and (ii) poorer households which cannot acquire such a range of goods, i.e., $\underline{\gamma}_{1} \leq \gamma<\gamma_{11}^{*}$. Country 1's labor force can also be divided into: (iii) households which are rich enough to buy all goods produced under IRS in country $2\left(0, q_{2}^{*}\right)$ plus some higher-indexed goods which are produced with the CRS technology, i.e., $\gamma \geq \gamma_{21}^{*}$, and (iv) poorer households which cannot acquire such a range of goods, i.e., $\underline{\gamma}_{1} \leq \gamma<\gamma_{21}^{*}$. The global middle class by the standards of country $i$ brings together households of type $\underline{\gamma}_{j} \leq \gamma<\gamma_{i j}^{*}$, $i, j=1,2$.

We define the global upper class by country $i$ standards with

$$
N_{i j}^{*}=\left(1-G_{j}\left(\gamma_{i j}^{*}\right)\right) L_{j}, i, j=1,2 .
$$


Finally, in equilibrium, one household of type $m$ consumes either domestic or foreign goods (but never a combination of the two). Given Eq. (2), the proportion of households in the world which consume country $i$-products is

$$
\lambda_{i}=1-\lambda_{j}=\frac{p_{j}^{1 / \delta}}{p_{i}^{1 / \delta}+p_{j}^{1 / \delta}} \Leftrightarrow \frac{p_{i}}{p_{j}}=\left(\frac{1-\lambda_{i}}{\lambda_{i}}\right)^{\delta}, i, j=1,2 \text { and } i \neq j,
$$

where $1-\lambda_{i}$ is also the proportion of income in country $i$ spent on imported products. Consequently, the width of the market for the producer of $q_{i}^{*}\left(D_{i}^{*}\right)$ depends on both the terms of trade and the size of the global upper class by country $i$ standards. It is given by

$$
D_{i}^{*}=\lambda_{i}\left[\sum_{j}\left(1-G_{j}\left(\gamma_{i j}^{*}\right)\right) L_{j}\right]=\frac{F}{\alpha-1}, i=1,2 .
$$

Note that all households characterized by $\gamma_{i j}^{*}$ are able to consume exactly $q_{i}^{*}$; they have similar purchasing power in terms of goods produced in country $i$. Thus, a household of type $\gamma$ in country $j$ may be rich enough in its own country to belong to the domestic upper class although from a global perspective it belongs to the world middle class.

\subsection{Trade balance and the global profit-multiplier}

The aggregate profit function in country $i$ is the sum of profits in all industries $q \in\left(0, q_{i}^{*}\right):$

$$
\pi_{i}=(\alpha-1) \frac{w_{i}}{A_{i}} \int_{0}^{q_{i}^{*}} D_{i}^{q} d q-\int_{0}^{q_{i}^{*}} w_{i} \frac{F}{\alpha} d q, i=1,2
$$

with the demand for good $q$ produced in country $i$ defined by

$$
D_{i}^{q}=\sum_{j} D_{i j}^{q}=\lambda_{i} \sum_{j}\left(1-G_{j}\left(\gamma_{i j}^{q}\right)\right) L_{j}, i=1,2,
$$

and where $\gamma_{i j}^{q}=p_{i} q /\left(w_{j} \bar{h}_{j} L_{j}+\pi_{j}\right)$ is the share ownership of the poorest household in country $j$ which can purchase $(0, q)$.

Using Eqs. (6) and (7), the above expression for profits can be integrated by change of variable and then by parts to yield

$$
\frac{\pi_{i}}{p_{i}}=\frac{\alpha-1}{\alpha} \lambda_{i}\left[\sum_{j} \frac{T_{i j}\left(w_{j} \bar{h}_{j} L_{j}+\pi_{j}\right)}{p_{i}}\right], i=1,2,
$$


with $T_{i j}=L_{j} \int_{\underline{\gamma}_{j}}^{\gamma_{i j}^{*}} \gamma d G_{j}(\gamma)$ denoting the share of income held by this middle class living in country $j$ which could potentially contribute to increase profits made by industries in country $i$. Thus, country $i$ profits depend on middle class real income in both trade partners expressed in terms of the price of country $i$-products, $T_{i j}\left(w_{j} \bar{h}_{j} L_{j}+\pi_{j}\right) / p_{i}$, and the proportion of the global middle class which consumes $i$-products $\left(\lambda_{i}\right)$ multiplied by the markup $(\alpha-1) / \alpha$. In the open economy, the combination of a large global middle class and price competitiveness sets the conditions for a relatively affluent consumer economy.

Our model ignores international borrowing and lending. Therefore, balanced trade requires

$p_{i} \int_{0}^{\infty} D_{i j}^{q} d q=p_{j} \int_{0}^{\infty} D_{j i}^{q} d q \Leftrightarrow \lambda_{i}\left(w_{j} \bar{h}_{j} L_{j}+\pi_{j}\right)=\lambda_{j}\left(w_{i} \bar{h}_{i} L_{i}+\pi_{i}\right), i, j=1,2$ and $i \neq j$.

Expenditure on goods produced in country $i$ by households living in country $j$ (left-hand side) equals expenditure on goods produced in country $i$ by households living in country $j$ (right-hand side). Because of Walras' Law, the clearing condition in Eq. (12) also ensures equality of demand and supply of labor within each trade partner.

Substituting the balanced trade condition (12) into the profit expression (11) yields profits per wage unit

$$
\frac{\pi_{i}}{w_{i}}=\frac{\frac{\alpha-1}{\alpha} \bar{h}_{i} L_{i}\left[\sum_{j} \lambda_{j} T_{i j}\right]}{1-\frac{\alpha-1}{\alpha}\left[\sum_{j} \lambda_{j} T_{i j}\right]}, i=1,2,
$$

where the global profit-multiplier $\left(M_{i}\right)$ is defined to be $1 /\left(1-\frac{\alpha-1}{\alpha}\left[\sum_{j} \lambda_{j} T_{i j}\right]\right)$.

\subsection{Trade equilibrium}

We first combine the balanced trade condition in Eq. (12) and the definition of $q_{i}^{*}$ as provided by Eq. (6). This yields the following relationship linking the shares of industrial profits in the hands of home and foreign marginal households with similar real income in terms of goods produced in country $i$ :

$$
\gamma_{i i}^{*}=\frac{1-\lambda_{i}}{\lambda_{i}} \gamma_{i j}^{*}, i=1,2 \text { and } i \neq j
$$


Secondly, we use Eqs. (8) and (13) to rewrite the market clearing condition (12) as follows

$$
\frac{\widehat{A_{1}}}{\widehat{A}_{2}}=\frac{M_{2}}{M_{1}} \frac{L_{2}}{L_{1}}\left(\frac{\lambda_{1}}{1-\lambda_{1}}\right)^{1+\delta},
$$

where $\widehat{A}_{i}=A_{i} \bar{h}_{i}$ measures labor efficiency in country $i$. The trade equilibrium values of $\gamma_{11}^{*}, \gamma_{12}^{*}, \gamma_{22}^{*}, \gamma_{21}^{*}$, and $\lambda_{1}=1-\lambda_{2}$ are determined by solving jointly Eqs. (9), (14), and (15). Let $G_{j}(\gamma)$ be the Pareto income distribution ${ }^{3}$ in country $j$. We are now in a position to show how international differences in income distribution, labor efficiency, or labor force size may produce either gains or losses from trade. Indeed, substituting Eq. (14) into Eq. (9) allows us to express $\gamma_{i i}^{*}$ as an implicit function of $\lambda_{1}$. The right-hand side of Eq. (15) can then be expressed as a one-variable function $\Psi\left(\lambda_{1}\right)$ which can be shown to be strictly increasing as long as $\delta>\alpha-2$, ensuring that the trade equilibrium is unique under relatively mild conditions.

\subsection{Average income, industrialization, and welfare}

In autarky, all profits that are distributed to the domestic middle class return as demand addressed to the home sectors. This implies the closed economy profit-multiplier $M_{i}=1 /\left(1-\frac{\alpha-1}{\alpha} T_{i}\right)$ in country $i$ with $T_{i}=L_{i} \int_{\underline{\gamma}_{i}^{*}}^{\gamma_{i}^{*}} \gamma d G_{i}(\gamma)$ and $\gamma_{i}^{*}$ the marginal household by country $i$ standards such that the breakeven condition $F /(\alpha-1)=N_{i}^{*}=\left(1-G_{i}\left(\gamma_{i}^{*}\right)\right) L_{i}$, is exactly satisfied.

Average income, the proportion of human capital employed in firms operating under IRS in country $i$, and welfare, all of which depend on the global profit-multiplier, can now be calculated under free trade and compared to their corresponding value under autarky. First, the average productivity in country $i$ is proportional to the multiplier

$$
\bar{y}_{i}=\frac{w_{i} \bar{h}_{i} L_{i}+\pi_{i}}{p_{i} L_{i}}=\frac{1}{1-\frac{\alpha-1}{\alpha}\left[\sum_{j} \lambda_{j} T_{i j}\right]} \frac{\widehat{A}_{i}}{\alpha}, i=1,2 .
$$

\footnotetext{
${ }^{3}$ We specify $G_{j}(\gamma)=1-\left(\underline{\gamma}_{j} / \gamma\right) \beta^{\beta_{j}}$ with $\beta_{j}>1$ and $\gamma \geq \underline{\gamma}_{j}>0$, where $\underline{\gamma}_{j}$ is the minimum share ownership of all domestic profit-making firms in country $j$. Note that $\int_{\underline{\gamma}_{j}}^{\infty} \gamma d G_{j}(\gamma)=1 / L_{j}$ which implies $\underline{\gamma}_{j}=\left(\beta_{j}-1\right) / \beta_{j} L_{j}$, so we have:

$$
T_{i j}=L_{i} \int_{\underline{\gamma}_{j}}^{\gamma_{i j}^{*}} \gamma d G_{j}(\gamma)=1-\left(\frac{\beta_{j}-1}{\beta_{j} L_{j} \gamma_{i j}^{*}}\right)^{\beta_{j}-1}, i, j=1,2 .
$$
}


Secondly, in addition to the variety of goods produced under conditions of increasing returns $\left(q_{i}^{*}\right)$, MSV suggest preferring an alternative measure of industrialization, namely, the proportion of human capital employed in country $i$ firms with access to IRS technology $\left(h_{i}^{I R S} / \bar{h}_{i} L_{i}\right)$. If we omit the human capital required to start production $\left(F A_{i}^{-1} q_{i}^{*}\right)$, it is equal to

$$
\frac{h_{i}^{I R S}}{\bar{h}_{i} L_{i}}=\frac{\lambda_{i}}{\bar{h}_{i} A_{i}} \sum_{j}\left(\gamma_{i j}^{*} N_{i j}^{*}+T_{i j}\right)\left(\frac{\left(w_{j} \bar{h}_{j} L_{j}+\pi_{j}\right)}{p_{i} L_{i}}\right), i=1,2 .
$$

Finally, given Eqs. (1), (4), and (8), the average welfare across each income class $\gamma$ of households living in country $j$ is given by

$$
\bar{V}_{j}^{\gamma}=\sum_{i}\left(\frac{\left(1+q_{i j}^{\gamma}\right)^{1-\sigma}-1}{1-\sigma} \int_{1-\lambda_{i}}^{1} m_{i}^{\delta} d m_{i}\right), j=1,2, \text { and } d m_{2}=-d m_{1},
$$

with $q_{i j}^{\gamma}=\gamma\left(w_{j} \bar{h}_{j} L_{j}+\pi_{j}\right) / p_{i}$.

Let us consider two identical countries. From Eqs. (9) and (15), there is a unique solution: $\lambda_{1}=\lambda_{2}=1 / 2$ and $\gamma_{11}^{*}=\gamma_{12}^{*}=\gamma_{22}^{*}=\gamma_{21}^{*}, \forall \delta$. In country $j$, using Eq. (18), we obtain

$$
\left[\int_{0}^{1 / 2}\left(1-m_{j}\right)^{\delta} d m_{j}+\int_{1 / 2}^{1}\left(m_{j}\right)^{\delta} d m_{j}\right]-\int_{0}^{1}\left(m_{j}\right)^{\delta} d m_{j}>0, j=1,2 .
$$

Hence, trade between two symmetric countries implies positive welfare gains from variety for both trade partners.

\section{Comparative statics}

\subsection{Differences in income distribution}

In this section, countries 1 and 2 differ only by their distribution of share ownership and human capital endowments $G_{j}(\gamma)$, i.e., labor efficiency is the same $\left(\widehat{A}_{1}=\widehat{A}_{2}\right)$ and labor force is the same $\left(L_{1}=L_{2}\right)$. Country $1(2)$ is characterized by a more (less) equal income distribution $\left(\beta_{1}>\beta_{2}\right)$. The equilibria under autarky and free trade are illustrated in Figure 1, where the lower left-hand quadrant depicts $\left(1-G_{j}(\gamma)\right) L_{j}$ together with the break even conditions, and the upper right-hand quadrant displays the corresponding Lorenz curve. 


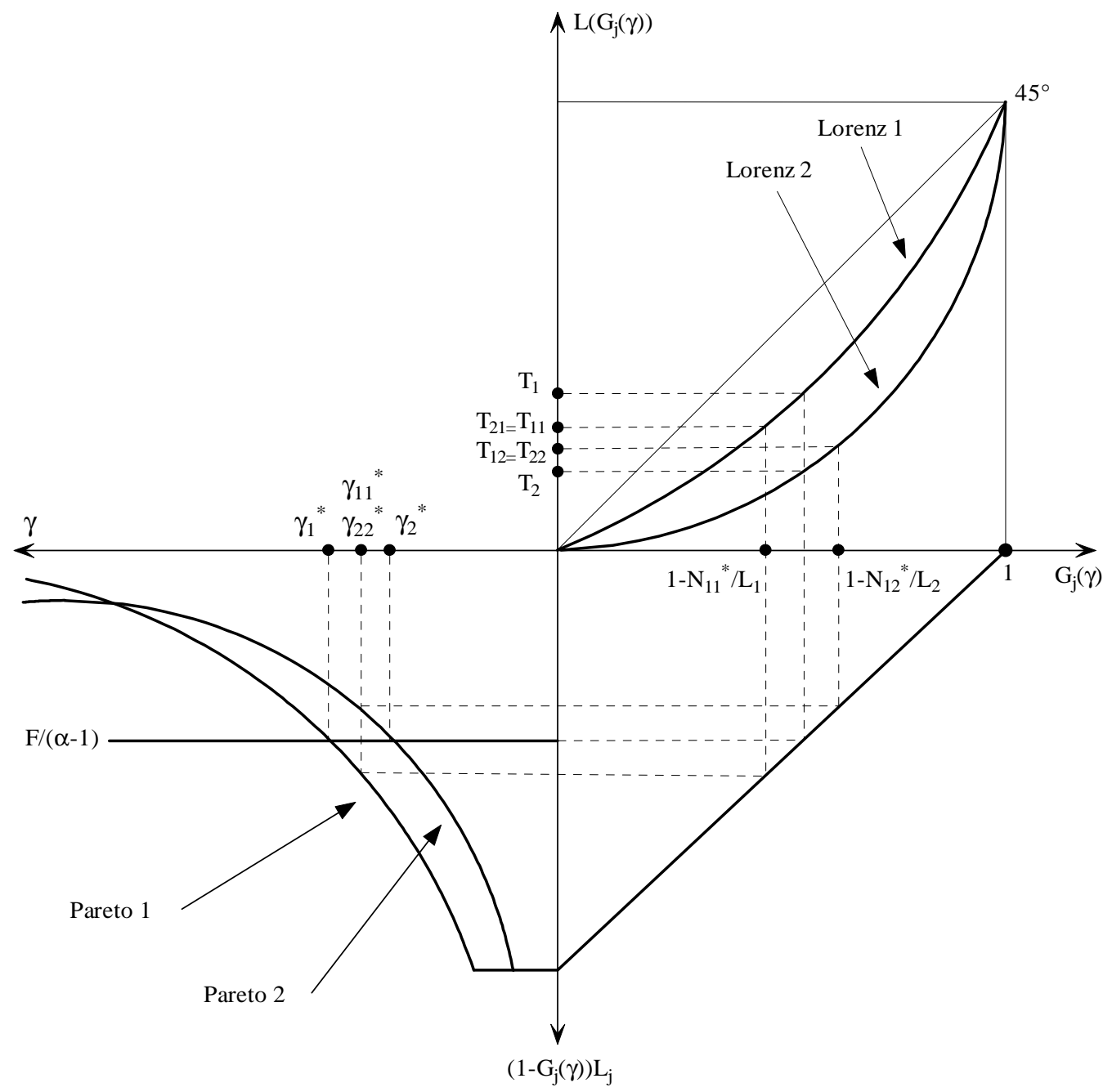

Figure 1: Equilibrium under autarky and free trade with differences in inequality.

In the no-trade equilibrium, the more equal trade partner is characterized by a larger mass of households who are able to contribute to the domestic profit-multiplier. As shown in Figure 1, the break even conditions yield $N_{1}^{*}=N_{2}^{*}$ which implies $T_{1}>T_{2}$. Therefore, the profit-multiplier is higher in country 1 which leads ceteris paribus to both a higher average productivity and a greater proportion of human capital employed in firms with access to IRS technologies. These differences across countries simply reflect the observation by MSV: a large middle class encourages mass production because it 
boosts the cumulative processes ${ }^{4}$.

The exposure of domestic industries to foreign competition modifies the customer base in each sector. Because labor efficiency and the size of the labor force are identical across countries, real wages are equalized under free trade. The simultaneous solution to Eqs. (9), (14) and (15) is $\lambda_{1}=\lambda_{2}=1 / 2$. Using Eqs. (9) and (14), it is then easily verified that the integrated world equilibrium also satisfies $\gamma_{11}^{*}=\gamma_{12}^{*}=\gamma_{21}^{*}=\gamma_{22}^{*}$ whatever $\gamma_{1}^{*} \gtreqless \gamma_{2}^{*}$. There are no longer two income distributions, but one global distribution of income where each type- $\gamma$ class of household spends its income equally on countries 1 and 2 products.

What are the effects of trade on country 1's profit-multiplier? First, using (9), and given that $N_{1}^{*}=N_{2}^{*}$ under autarky, we have $\left|N_{11}^{*}-N_{1}^{*}\right|=$ $\left|N_{12}^{*}-N_{1}^{*}\right|$. Secondly, recall that the Lorenz curve is convex, and its slope in $G_{j}(\gamma)$ is equal to $\gamma L_{j}$. This allows us to conclude for country 1:

$$
\begin{aligned}
\gamma_{1}^{*} & \gtreqless \gamma_{2}^{*} \Rightarrow \gamma_{11}^{*} \lesseqgtr \gamma_{1}^{*} \\
& \Rightarrow T_{1} \gtreqless T_{11}, N_{11} \gtreqless N_{1}, \text { and } T_{22}=T_{12} \gtreqless T_{2} \\
& \Rightarrow \frac{\left|T_{1}-T_{11}\right|}{\left|N_{11}^{*}-N_{1}^{*}\right|} \gtreqless \gamma_{11}^{*}=\gamma_{12}^{*} \gtreqless \frac{\left|T_{12}-T_{2}\right|}{\left|N_{2}^{*}-N_{12}^{*}\right|} \\
& \Rightarrow T_{11}+T_{12}<T_{1}+T_{2} \Rightarrow \frac{1}{2}\left(T_{11}+T_{12}\right)<T_{1} .
\end{aligned}
$$

Trade shifts country 1's middle class demand away from goods produced in country 1 , which weakens its multiplier. Country 1 thus sees the shrinking of those markets where increasing returns to scale are strongest under autarky, thereby lowering human capital employed in country 1 firms operating under IRS. Even though the upper class is larger in country 2, it mainly contributes to increasing the demand for goods with the highest income elasticities of demand produced in country 1. Since most of them are produced with the CRS technology, their increased output cannot outweigh the decrease in the average productivity in country 1.

The opposite occurs in country 2, thanks to the mass middle class in country 1 which contributes to enlarging the market share of goods produced

\footnotetext{
${ }^{4}$ Note that the alternative case where $\left(1-G_{1}(\gamma)\right) L_{1}$ crosses $\left(1-G_{2}(\gamma)\right) L_{2}$ somewhere above $F /(\alpha-1)$, implies $\gamma_{1}^{*}<\gamma_{2}^{*}$ and, therefore, $q_{1}^{*}$ may be smaller than $q_{2}^{*}$ despite country 1 being more equal than country 2 . Nevertheless, whatever $\gamma_{1}^{*} \gtreqless \gamma_{2}^{*}$, we still have $T_{1}>T_{2}$, $\bar{y}_{1}>\bar{y}_{2}$, and $h_{1}^{I R S} / \bar{h}_{1} L_{1}>h_{2}^{I R S} / \bar{h}_{2} L_{2}$.
} 
under conditions of increasing returns. Whatever $\gamma_{1}^{*} \gtreqless \gamma_{2}^{*}$, we have

$$
\frac{1}{2}\left(T_{22}+T_{21}\right)>\frac{1}{2}\left(T_{22}+L_{2} \int_{\underline{\gamma}_{2}}^{\gamma^{c}} \gamma d G_{2}(\gamma)\right)>T_{2}
$$

where $\gamma^{c}$ is defined by $\int_{\underline{\gamma}_{2}}^{\gamma^{c}} d G_{2}(\gamma)=1-N_{11}^{*} / L_{1}$. Hence, the benefits from trade for country 2 increase with the degree of equality in the income distribution in country 1.

Equations (16) and (18) are now used to solve the output and welfare levels of the two income classes. As long as $\widehat{A}_{1}=\widehat{A}_{2}$ and $L_{1}=L_{2}$, the world market shares of home and foreign products and the preference parameter $m$ of the marginal household which is indifferent between the home and the foreign variety, are equal to $1 / 2$.

In country 2 , all households can purchase a larger range of goods in the trade equilibrium. Moreover, each household can pick its ideal variety of any good $q$ which means a complementary source of positive gains from trade for half of them. Hence, all households favor trade independently of their relative standing on the domestic income scale and of their preference for domestic versus foreign goods.

In country 1, all households now consume a smaller range of goods. Both varieties of each good $q$ are offered at the same price, so for households which rate domestic goods higher than foreign goods, product variety is not a source of gains from trade. Free trade is welfare-reducing for these households. Those which prefer foreign products may not all be compensated by variety gains. In the light of (18), whatever the value of $\gamma$, the household which is indifferent between the domestic and the foreign variety, i.e., $m_{1}=m_{2}=$ $1 / 2$, differs from the marginal household which prefers trade. Even though the mass of households is equally split between households which buy the domestic good and those which prefer the corresponding foreign substitute, less than half of them favor trade. More specifically, the higher the relative price sensitivity of demand $(\delta)$, the more the gains from variety outweigh the losses in the range of goods they can purchase under free trade.

\subsection{Differences in labor efficiency}

Now we discuss the relationship between international demand spillovers and the growth (or decline) of industrial activities in economies that differ only by 
their labor efficiency. In this section, country 1 has a technological advantage in producing all goods: $\widehat{A}_{1}>\widehat{A}_{2}$. In autarky, each household in country 1 has a higher purchasing power which originates from higher labor efficiency and not from a larger domestic profit-multiplier. Hence, in terms of human capital employed in firms where IRS technology is implemented, country 1 does better than country 2 .

When autarky ends and free trade begins, the more the labor force in country 1 is efficient in producing goods, the more competitive are firms located in country 1 . The trade equilibrium is obtained when excess demand in the two countries is equal and opposite. Figure 2 (right-hand quadrant) illustrates the simultaneous solution to Eqs. (9), (14), and (15). When both trade partners share the same Pareto income distribution, i.e., $\beta_{1}=\beta_{2}$, using Eq. (14) and substituting Eq. (9) into Eq. (15) yields

$$
\frac{\widehat{A}_{1}}{\widehat{A}_{2}}=\Psi\left(\lambda_{1}\right)=\left(\frac{\lambda_{1}}{1-\lambda_{1}}\right)^{1+\delta} \frac{\frac{1}{\alpha}+\frac{\alpha-1}{\alpha}\left(\frac{F}{\alpha-1}\right)^{\frac{\beta-1}{\beta}}\left(\phi_{1}\left(\lambda_{1}\right)\right)^{\frac{1}{\beta}}}{\frac{1}{\alpha}+\frac{\alpha-1}{\alpha}\left(\frac{F}{\alpha-1}\right)^{\frac{\beta-1}{\beta}}\left(\phi_{2}\left(1-\lambda_{1}\right)\right)^{\frac{1}{\beta}}} \frac{L_{2}}{L_{1}},
$$

where we used $\sum_{j} \lambda_{j} T_{i j}=1-(F /(\alpha-1))^{(\beta-1) / \beta} \phi_{i}\left(\lambda_{i}\right)^{1 / \beta}$, with $\phi_{1}\left(\lambda_{i}\right)=$ $\lambda_{i} L_{1}^{1-\beta}+\left(1-\lambda_{i}\right)^{\beta} \lambda_{i}^{1-\beta} L_{2}^{1-\beta}, \phi_{2}\left(\lambda_{i}\right)=\lambda_{i} L_{2}^{1-\beta}+\left(1-\lambda_{i}\right)^{\beta} \lambda_{i}^{1-\beta} L_{1}^{1-\beta}, \phi_{i}\left(\lambda_{i}\right)=\infty$ for $\lambda_{i}=0$, and $\phi_{i}\left(\lambda_{i}\right)=L_{i}^{1-\beta}$ for $\lambda_{i}=L_{i} /\left(L_{i}+L_{j}\right), i \neq j$. The implicit function theorem then yields $\partial \lambda_{1} / \partial\left(\widehat{A}_{1} / \widehat{A}_{2}\right)>0$.

As shown in the right-hand quadrant of Figure 2 where Eq. (19) is depicted, balanced trade requires a terms-of-trade adjustment against country 1 , where the fraction of world income spent on goods produced in country $1\left(\lambda_{1}\right)$ increases with the widening of the technological gap $\left(\widehat{A}_{1} / \widehat{A}_{2}\right)$. Under free trade, the more competitive trade partner captures a larger share of the whole range of global markets.

The left-hand quadrant of Figure 2 depicts Eq. (9) for countries 1 and 2 and the free trade equilibrium values of $\gamma_{11}^{*}$ and $\gamma_{22}^{*}$, where

$$
\gamma_{i i}^{*}=\frac{\beta-1}{\beta}\left(\frac{\alpha-1}{F}\right)^{1 / \beta} \phi_{i}\left(\lambda_{i}\right)^{1 / \beta}, i=1,2 .
$$

First, if and only if $d \phi_{i}\left(\lambda_{i}\right) / d \lambda_{i} \lesseqgtr 0$, we have $\partial \gamma_{i i}^{*} / \partial \lambda_{i} \lesseqgtr 0$. Given that $d^{2} \phi_{i}\left(\lambda_{i}\right) / d \lambda_{i}^{2}>0, \phi_{i}\left(\lambda_{i}\right)$ is therefore characterized by one minimum ${ }^{5}$. Second,

\footnotetext{
${ }^{5}$ As illustrated in the left-hand quadrant of Figure $2, \phi_{1}\left(\lambda_{1}\right)$ and $\phi_{2}\left(\lambda_{1}\right)$ must cross
} 
the type of the marginal household in the no-trade equilibrium is given by

$$
\gamma_{i}^{*}=\frac{\beta-1}{\beta}\left(\frac{\alpha-1}{F}\right)^{1 / \beta} L_{i}^{(1-\beta) / \beta}, i=1,2,
$$

which allows us to conclude

$$
\lambda_{i} \lesseqgtr \frac{L_{i}}{L_{i}+L_{j}} \Leftrightarrow \phi_{i}\left(\lambda_{i}\right) \gtreqless L_{i}^{1-\beta} \Leftrightarrow \gamma_{i i}^{*} \gtreqless \gamma_{i}^{*}, i, j=1,2 \text { and } i \neq j .
$$

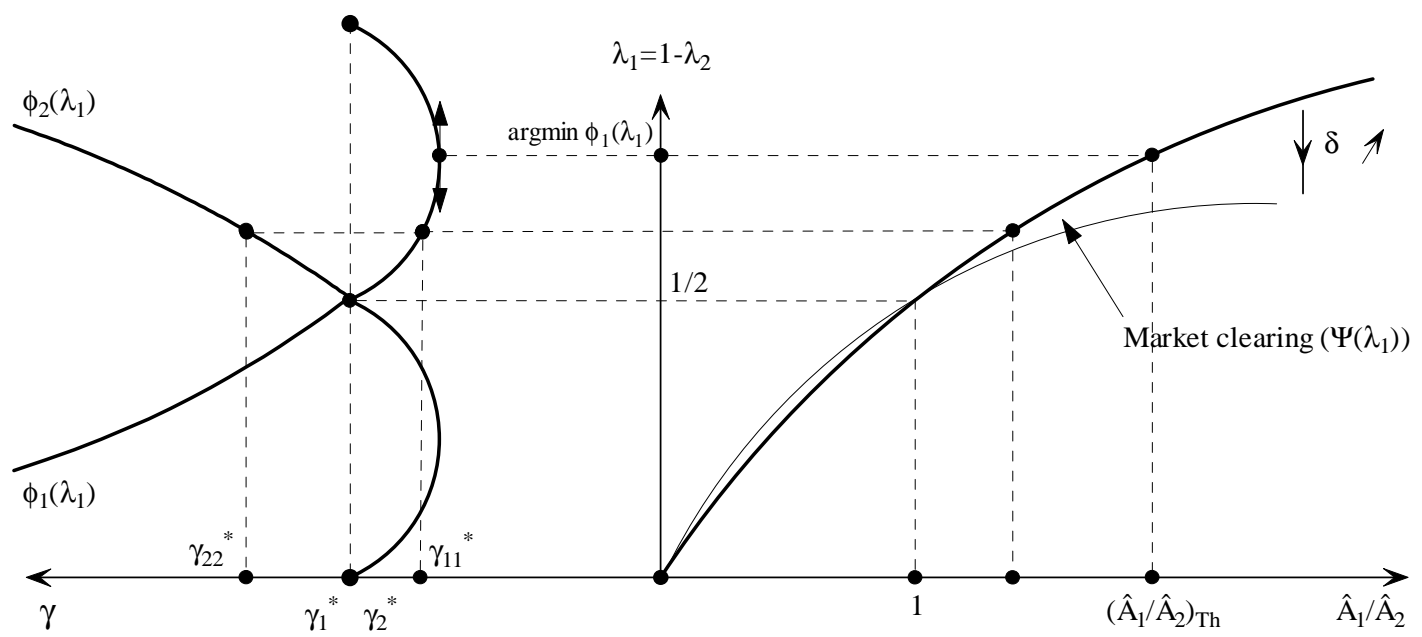

Figure 2: International equilibrium with differences in labor efficiency.

We are now ready to derive the consequences of a move from autarky to free trade when $\widehat{A}_{1}>\widehat{A}_{2}$ : markets clear with $\lambda_{1}>L_{1} /\left(L_{1}+L_{2}\right)$ which implies $\gamma_{11}^{*}<\gamma_{1}^{*}$ and $\gamma_{22}^{*}>\gamma_{2}^{*}$. This yields an increase (decrease) in country 1 (2)'s multiplier ${ }^{6}$. Global demand complementarities exacerbate international disparities. In terms of average income, trade penalizes the economy with the each other in $\lambda_{1}=\lambda_{2}=1 / 2$. Moreover, using Eq. (20), it is easy to check that when $L_{2} / L_{1}=1$, we have

$$
\arg \min \left(\phi_{1}\left(\lambda_{1}\right)\right)>1 / 2>\arg \min \left(\phi_{2}\left(\lambda_{1}\right)\right)
$$

${ }^{6}$ Replacing Eqs. (20) and (21) in their profit-multiplier's definition under respectively free trade and autarky, we obtain similar functions $M_{i}(\gamma)$, where $\partial M_{i}(\gamma) / \partial \gamma<0$, for either $\gamma_{i}^{*}$ or $\gamma_{i i}^{*}$. 
less efficient labor force and favors the technically more advanced country. Overall, the opening to trade raises the proportion of the labor force employed by firms with access to IRS technology in the advanced economy. It shrinks in the backward country even though the deterioration in the latter is not uniform across industries. Some are affected negatively while others are affected positively. In fact, labor market clearing in country 2 leads the variety of goods produced under IRS $\left(q_{2}^{*}\right)$ to rise, allowing firms which produce goods with relatively higher income elasticities of demand to benefit from country 1's middle-class buying power.

More to the point, the customer base of more competitive country 1 firms operating under IRS expands in the area of goods with low income elasticities of demand. A large proportion of households in country 2 contributes to boosting the production of low-indexed goods produced in country 1 , strengthening IRS in these industries. This is at the expense of their less competitive counterparts in country 2. Note that the proportion of domestic income which may potentially buy goods produced in country 1 using IRS technologies is indeed greater in country 2 than in country 1 . We have $\gamma_{12}^{*}>\gamma_{1}^{*}>\gamma_{11}^{*}$, where type- $\gamma_{12}^{*}$ households in country 2 have a purchasing power similar to that of type- $\gamma_{11}^{*}$ households in country 1 . Hence, there is a proportion $\lambda_{1}$ of $L_{2} G_{2}\left(\gamma_{12}^{*}\right)$ and $L_{1} G_{1}\left(\gamma_{11}^{*}\right)$, where $L_{2} G_{2}\left(\gamma_{12}^{*}\right)>L_{1} G_{1}\left(\gamma_{11}^{*}\right)$, which contributes to increasing profits in country 1 firms operating under IRS. If the type- $\gamma_{12}^{*}$ household is rich by country 2 standards, its spending pattern is similar to that of the middle class in country 1 . Thus, country 1 producers of goods with the lowest income elasticities of demand produce at a more efficient scale and earn higher profits. The same reasoning applies to explain why there is a contraction of rival industries' activity in country 2 . We have $\gamma_{21}^{*}<\gamma_{2}^{*}<\gamma_{22}^{*}$ which yields $T_{21}<T_{22}$. Therefore, there is only a proportion $\lambda_{2}<1 / 2$ of $L_{1} G_{1}\left(\gamma_{21}^{*}\right)$, where $\gamma_{21}^{*}<\gamma_{11}^{*}$, and $L_{2} G_{2}\left(\gamma_{22}^{*}\right)$, where $\gamma_{22}^{*}<\gamma_{12}^{*}$, which contributes to profits made by country 2 firms using IRS technologies.

Our model thus identifies a demand-side channel through which trade integration contributes to the gap for countries lagging behind the technological frontier. In country 2 which is less productive, free trade introduces more competitive foreign industries generating the infant industry argument for protection. It was sometimes used in Brazil in the 1960s and 1970s and in India for most of the second half of the twentieth century to pursue importsubstitution policies relying on enormous domestic market to modernize their respective industries. Whereas, South Korea industrialized in the 1960s and 
1970s by committing to an export-led growth strategy to compensate for its limited domestic demand ${ }^{7}$. Both strategies have in common to utilize fixing of prices instead of letting them adjust to the free play of market forces (see Ray 1998).

Finally, we heuristically discuss welfare gains from trade. First, the terms of trade adjustment and parameter $\delta$ determine the proportion of world demand addressed to each sector and, therefore, the growth or decline of average productivity when countries engage in free trade. Secondly, according to their preferences and relative price, households may choose their ideal variety produced either at home or abroad. In country 1, average productivity increases. Since more than half the households buy domestic varieties, a majority gains from trade. To this proportion $\lambda_{1}>1 / 2$, one must add a positive proportion of the remaining households for which gains from variety more than outweigh the loss of purchasing power incurred by the higher relative price of the imported variety. In contrast, average productivity decreases in country 2. This loss is only partially offset by the gains from variety and by access to cheaper goods from abroad.

\subsection{Differences in labor force size}

We turn to the analysis of the impact of trade on economies which differ only in the size of their labor force. Let country 2 be the larger country $\left(L_{2}>L_{1}\right)$. Because IRS in autarky depend only on the domestic market size, they are stronger in country 2 . For all goods $q$ produced under IRS, the unit costs are lower in Country 2 where each industry produces a greater quantity than its foreign counterpart $\left(D_{2}^{q}=L_{2}\left(1-G_{2}\left(\gamma_{2}^{q}\right)\right)>D_{1}^{q}=L_{1}\left(1-G_{1}\left(\gamma_{1}^{q}\right)\right), \forall q\right)$. Now we question whether free trade is a good thing for each country or only for one of them? In which case, is it the small or the large country that loses from trade?

\footnotetext{
${ }^{7}$ In the words of Irwin (2008): "The [infant industry] argument holds that certain new industries should be protected from foreign competition in the expectation that they will eventually mature and successfully compete against more experienced foreign rivals... In the modern literature, [it] hinges on 'dynamic learning effects', which allow an industry that is not currently competitive to become so after a temporary period of protection." In a recent paper, Melitz (2005) shows that how and when infant industries should be protected depends on the industry's learning potential, the speed of learning, and the degree of substitutability between the domestic and foreign goods. In view of the static nature of our model, it lies beyond its scope to discuss this issue further.
} 
Suppose there is an equal share of world income devoted to goods produced in each country, then there will be excess labor demand in country 1 requiring a terms of trade adjustment. To guarantee labor-market equilibrium in both trade partners, the proportion of households which consume country 1 goods $\left(\lambda_{1}\right)$ must be less than $1 / 2$. Interesting enough, $\lambda_{1}$ remains greater than $L_{1} /\left(L_{1}+L_{2}\right)$ as long as the relative price sensitivity of demand is sufficiently low ${ }^{8}$. Let country 1 import relatively cheaper varieties from country 2 in a proportion $1-\lambda_{1}$ with $\lambda_{1}=L_{1} /\left(L_{1}+L_{2}\right)$. For those households in country 1 which buy country 2 goods, this implies purchasing power gains which allow them to increase the range of goods they can import. Excess labor demand in country 2 results, which leads to an improvement in its terms of trade. Eventually, $\lambda_{1}$ rises above $L_{1} /\left(L_{1}+L_{2}\right)$ which implies $\gamma_{11}^{*}<\gamma_{1}^{*}$ (see Eq. (22)). Hence, country 1's multiplier rises by opening to trade while the opposite holds true in country 2 where $\lambda_{2}<L_{2} /\left(L_{1}+L_{2}\right)$ which implies a decrease in country 2's multiplier. International demand complementarities benefit the small economy at the expense of the larger trade partner.

The intuition as to why country 1 multiplier rises is that the trade-induced enlargement of demand for the small country's firms is biased towards those operating under IRS, thanks to the large number of country 2's relatively poor households in the world distribution of income. Given Eq. (14), $\gamma$ income classes of households with similar purchasing power in terms of goods produced in country $1(2)$, are such that $\gamma_{11}^{*}>\gamma_{12}^{*}\left(\gamma_{22}^{*}<\gamma_{21}^{*}\right)$. Since average productivity is greater in country 2 and using Eq. (20), this implies $\gamma_{21}^{*}>\gamma_{11}^{*}>\gamma_{22}^{*}>\gamma_{12}^{*}$. If the type- $\gamma_{12}^{*}$ household is relatively poor by country 2 standards, it is middle class by country 1 standards. With $L_{1}<L_{2}$ and $\lambda_{1}>L_{1} /\left(L_{1}+L_{2}\right)$, demand for goods produced by country 1 firms using IRS technologies is therefore higher under free trade, increasing profits. The counterpart in country 2 is a fall in IRS production activities at the aggregate level.

To sum up, the small country narrows the range of its domestic IRS industrial activities to concentrate more productively on fewer high-priority product niches, whereas in the large country, the range of industries operating

\footnotetext{
${ }^{8}$ Recall that $\Psi\left(\lambda_{1}\right)$ is monotonically increasing with $\lambda_{1}$. Then, for $L_{1} / L_{2}<1, \widehat{A}_{1} / \widehat{A}_{2}=$ 1 , and $\delta>(\beta-1) / \beta$, Equation (19) implies

$$
\Psi\left(\frac{L_{1}}{L_{1}+L_{2}}\right)<\Psi\left(\lambda_{1}\right)=1 \Rightarrow \lambda_{1}>\frac{L_{1}}{L_{1}+L_{2}} .
$$
}


under IRS increases.

It is not entirely surprising that our results contrast with those in Ethier (1982) where the large country specializes in the IRS sector and always gains from trade whereas the small country may lose if it is not too small relative to its trade partner and IRS are sufficiently weak. Our settings differ markedly: trade in two homogeneous versus many differentiated goods, and external versus internal increasing returns. However, as long as $\widehat{A}_{1}=\widehat{A}_{2}$ and $L_{1}<L_{2}$, we can stress that if country 2 in our framework is tempted by protection, the latter should be considered on a permanent basis which is the Graham's (1923) case for protection as discussed in Ethier (1982), not the infant industry argument for protection as discussed above.

\section{Technological catch-up and convergence}

We now trace out the consequences of a technically backward partner (country 2) narrowing its technological gap under the free trade regime. Suppose that $\widehat{A}_{1}>\widehat{A}_{2}, L_{1}=L_{2}$, and $\beta_{1}=\beta_{2}$. An increase in $\widehat{A}_{2}$ requires a fall in the relative price of country 2 goods to keep trade between the two countries in balance. It eventually translates into an increase in the range of goods the expanding global middle class can purchase: $\lambda_{1}$ and $\gamma_{22}^{*}$ unambiguously decrease (see Figure 2) which implies a higher global profit-multiplier. Efficiency gains in country 2 allow its industries to sustain the rising demand for all the goods they produce. The larger customer base has two sources: (i) a larger share of world markets caused by the increase in $\lambda_{2}$, (ii) a larger world market due not only to country 2's labor productivity increase, but also to magnified international demand complementarities which raise international demand.

There is an ambiguous impact of technological catch-up on the technically more advanced trade partner, depending on whether the initial technological gap starts above or below some threshold $\left(\left(\widehat{A}_{1} / \widehat{A}_{2}\right)_{T h}\right)$. Suppose that $\widehat{A}_{1} / \widehat{A}_{2}<\left(\widehat{A}_{1} / \widehat{A}_{2}\right)_{T h}$ as depicted in Figure 2. Gains in factor efficiency in the lagging trade partner lead the global profit-multiplier in the advanced country to fall $\left(\gamma_{11}^{*}\right.$ increases and $\left.\partial M_{1} / \partial \gamma_{11}^{*}<0\right)$ while the opposite occurs if $\widehat{A}_{1} / \widehat{A}_{2}$ starts above $\left(\widehat{A}_{1} / \widehat{A}_{2}\right)_{T h}$.

What is the intuition behind this ambiguous impact? Before technological catch-up, world demand for country 1 products is divided into three categories: (i) a range of goods with the lowest income elasticities of demand 
$(0, q)$ that all households from both trade partners are able to purchase, (ii) an intermediate range of goods $(\underline{q}, \bar{q})$ which is acquired by all country 1 households and a smaller proportion of country 2 households, (iii) a range of goods with higher income elasticities of demand that only rich enough households from either trade partner can purchase. As far as the first range of goods is concerned, the world demand for country 1 products falls as a result of the decrease in $\lambda_{1}$. The net impact on the second and third categories of an increase in $\widehat{A}_{2}$ depends on the extent of two effects which shift demand for these products in opposite directions: the decrease in the share of world income spent on goods produced by country 1 firms, and the increase in the purchasing power of the global middle class by country 1 standards.

Figure 2 displays the case where $\widehat{A}_{1} / \widehat{A}_{2}$ is below $\left(\widehat{A}_{1} / \widehat{A}_{2}\right)_{T h}$. In country 1 , the loss of competitiveness mostly harms producers of goods with low income elasticities of demand. Aggregate profits fall because country 1 IRS firms producing goods with lower income elasticities of demand now produce at a less efficient scale. However, the rise in average productivity in country 2 spills over to country 1 sectors producing goods with higher income elasticities of demand. If the relative share of IRS firms' production in total output decreases, there is an increase in the range of country 1 firms that are able to implement IRS technologies. Indeed, the rising demand from the emerging global middle class which accompanies technological catch-up in country 2 spurs demand for goods with high income elasticities of demand.

In contrast to the Ricardian model with non-homothetic preferences in Matsuyama (2000), a scenario of immiserizing growth in country 2 is impossible here. In his framework, country 2 specializes in goods with low income elasticities whose demand does not increase in response to the fall in prices. Thus, it may lose from its terms of trade deterioration associated with a labor productivity improvement. In fact, the relatively cheaper goods imported from country 2 only provide the opportunity for rich households in country 1 to expand their consumption of goods with high income elasticity of demand that are only produced in country 1 . In the present model, our preference assumptions together with international imperfect competition do not imply complete geographic specialization. Depending on $\delta$ and the terms of trade adjustments, technical catch-up enables the lagging trade partner to expand its scale of output and attain markup opportunities which are ruled out in a Ricardian analysis. Country 2 cannot lose from its productivity improvement, while its trade partner may either win or lose depending on the initial technological gap. 
Finally, suppose that country 1 is not only more productive $\left(\widehat{A}_{1}>\widehat{A}_{2}\right)$ but also smaller than country $2\left(L_{1}<L_{2}\right)$. Under autarky, the large emerging country benefits from a higher multiplier thanks to its population' size, while the small industrialized country has a higher income per capita because of its more efficient labor force. What is the impact of trade on countries 1 and 2's aggregates when $\beta_{1}$ is still assumed to be equal to $\beta_{2}{ }^{9}$ ? Comparative statics in Sections 4.2 and 4.3 show that country 1 (country 2 ) must see its multiplier increase (shrink) while it moves from autarky to free trade, thereby raising (lowering) its average real income.

Consider now the effect of an increase in labor efficiency in country 2 . First, terms of trade deteriorate in country 2. Secondly, recall that the Gini coefficient of the Pareto distribution is defined to be $1 /(2 \beta-1)$. Interestingly enough, using Eq. (20), we obtain ${ }^{10}$ :

$$
\frac{L_{2}}{L_{1}}>(2 \beta-1)^{1 /(\beta-1)} \Rightarrow \arg \min \left(\phi_{1}\left(\lambda_{1}\right)\right)<1 / 2 \text { and } \arg \min \left(\phi_{2}\left(\lambda_{1}\right)\right)<1 / 2 \text {. }
$$

This allows us to conclude that as long as $\widehat{A}_{1} / \widehat{A}_{2}>\left(\widehat{A}_{1} / \widehat{A}_{2}\right)_{T h}$ and $L_{2} / L_{1}>$ $(2 \beta-1)^{1 /(\beta-1)}$, Eq. (20) is increasing where $\lambda_{1}$ clears markets, implying lower $\gamma_{11}^{*}$ and $\gamma_{22}^{*}$. Technological catch-up in the large emerging country therefore yields an increase in both country 1 and country 2's global profit-multipliers and average real incomes. Moreover, convergence occurs with $\bar{y}_{1} / \bar{y}_{2}$ falling relative to the above free trade baseline.

\section{Conclusion}

The literature on international trade and development has concentrated on international technology spillovers, but neglected international demand spillovers. Our contribution seeks to fill the gap. It presents a multi-industry and twocountry general equilibrium model in which demand spillovers contribute to propagate increasing returns to scale both across industries and national boundaries. We relax the traditional assumption of homothetic preferences to focus on the role played by the global income distribution, both in the

\footnotetext{
${ }^{9}$ Based on the World Income Inequality data base, Mukhopadhaya (2004) classifies China and the US in the same group of countries where the group includes countries with Gini coefficients between 0.40 and 0.45 .

${ }^{10}$ The Penn World Tables (see Heston et al. 2006) indicate that China was about four times more populous than the United States in 2004.
} 
international structure of production and in the trade pattern between countries that differ in size. Despite the difficulty of testing some of the ideas presented above, empirical work is now needed to assess the importance of international demand spillovers at both aggregate and sectoral levels.

Our results raise additional questions which could profitably be addressed in the future. First, one implication of our model is that income transfers have very different effects depending on whether they are between or within countries or if they occur within a leader or a follower economy. Let us consider a policy that would promote a more equal distribution in country $i$ of an amount $\tau\left(w_{i} \bar{h}_{i} L_{i}+\pi_{i}\right) / L_{i}$ among all households in country $i$, where $\tau$ is the marginal tax rate. Let $\gamma^{\tau}=(1-\tau) \gamma+\tau / L_{i}$ denote the associated post tax ownership share of a type- $\gamma$ household. The redistribution eventually exerts a positive effect on the adoption of IRS technology in both trade partners, therefore demonstrating the potential benefits of reducing both across- and within-country inequalities.

Secondly, our contribution focuses on the dichotomy between autarky and free trade. Endogenous growth models with either variety-expanding or quality-upgrading of products, which introduce differing income elasticities of demand for different goods, have recently emerged in the literature. For example, Foellmi and Zweimüller (2006) examine the impact of non-homothetic preferences and therefore inequality on innovation and consequent economic growth. Solow (2005) expresses some surprise at the lack of attention to the interaction of demand-side and supply-side variations, i.e., to economics of the medium run, within multi-industry and multi-country growth frameworks. These interactions remain a valuable, open, and empirically relevant issue to be addressed.

\section{Appendix: International price equilibrium}

When entering the international market, the home firm with access to IRS technology in industry $q$ may face competition from either the rival firm abroad with access to IRS technology or a competitive fringe of foreign firms. This Appendix shows that the unique Nash equilibrium price strategy for a country $i$ monopolist entering the international market, is to set prices at $\alpha w_{i} / A_{i}$ provided that the world distribution of real income is smooth enough. Proof. A country 1 monopolist entering the global marketplace cannot set a price higher than the effective competitive price in country $1\left(\alpha w_{1} / A_{1}\right)$ 
without giving way to a competitive fringe of domestic firms. Hence, the question to be solved is whether it may increase its profits by lowering its price unilaterally below $p_{1}=\alpha w_{1} / A_{1}$, i.e., while all other firms in the world economy keep their price unchanged. For the answer to be negative, the marginal profit should satisfy

$$
\frac{\partial \pi_{1}^{q}}{\partial \widetilde{p}_{1}^{q}}=\frac{\partial \widetilde{D}_{1}^{q}}{\partial \widetilde{p}_{1}^{q}}\left(\widetilde{p}_{1}^{q}-\frac{w_{1}}{A_{1}}\right)+\widetilde{D}_{1}^{q}>0 \Leftrightarrow-\frac{\partial \widetilde{D}_{1}^{q}}{\partial \widetilde{p}_{1}^{q}} \widetilde{p}_{1}^{q}\left(\frac{\widetilde{p}_{1}^{q}-w_{1} / A_{1}}{\widetilde{p}_{1}^{q}}\right)<1,
$$

with $\widetilde{p}_{1}^{q} \leq p_{1}$, and where $\widetilde{D}_{1}^{q}$ is the effective demand for the variety of good $q$ produced in country 1 at $\widetilde{p}_{1}^{q}$. In other words, the price elasticity of demand multiplied by the price-cost margin should not exceed unity.

Using Eq. (2), if the monopolist charges $\widetilde{p}_{1}^{q}$, the country 1 variety of good $q$ is preferred by a type- $m$ household if

$$
\frac{m_{1}^{\delta}}{\widetilde{p}_{1}^{q}}(1+q)^{-\sigma}>\frac{\left(1-m_{1}\right)^{\delta}}{p_{2}}(1+q)^{-\sigma} \Leftrightarrow m_{1}>1-\widetilde{\lambda}_{1},
$$

with $\widetilde{\lambda}_{1}=p_{2}^{1 / \delta} /\left(\left(\widetilde{p}_{1}^{q}\right)^{1 / \delta}+p_{2}^{1 / \delta}\right)$, and $p_{2}=\alpha w_{2} / A_{2}$.

Note that $\widetilde{p}_{1}^{q}<p_{1}$ implies $\widetilde{\lambda}_{1}>\lambda_{1}$. The monopolist's ex post customer base may now be divided into two categories: households of type $m_{1}>$ $1-\lambda_{1}$ which prefer goods produced in country 1 , and households of type $1-\lambda_{1} \geq m_{1}>1-\widetilde{\lambda}_{1}$ which prefer, other things being equal, product varieties produced in country 2 , except for the country 1 variety of good $q$.

Let us define $\widetilde{q} \leq q$ produced in country 1 such that

$$
\frac{m_{1}^{\delta}}{\widetilde{p}_{1}^{q}}(1+q)^{-\sigma}=\frac{m_{1}^{\delta}}{p_{1}}(1+\widetilde{q})^{-\sigma} \Rightarrow \widetilde{q}=\left(\frac{p_{1}}{\widetilde{p}_{1}^{q}}\right)^{-1 / \sigma}(1+q)-1 .
$$

Among the first category of households, customers for the country 1 variety of $\operatorname{good} q$ include all those which are rich enough to buy $\widetilde{q}$, i.e., households of type $\gamma \geq \gamma_{1 j}^{\widetilde{q}}$, with

$$
\gamma_{1 j}^{\widetilde{q}}=\frac{\left(\widetilde{p}_{1}^{q}\right)^{1 / \sigma}\left(p_{1}\right)^{(\sigma-1) / \sigma}(1+q)-p_{1}}{w_{j} \bar{h}_{j} L_{j}+\pi_{j}}, j=1,2 .
$$

Similarly, we define $\widehat{q} \leq q$ produced in country 2 such that

$$
\frac{m_{1}^{\delta}}{\widetilde{p}_{1}^{q}}(1+q)^{-\sigma}=\frac{\left(1-m_{1}\right)^{\delta}}{p_{2}}(1+\widehat{q})^{-\sigma} \Rightarrow \widehat{q}=\left(\frac{1-m_{1}}{m_{1}}\right)^{\delta / \sigma}\left(\frac{\widetilde{p}_{1}^{q}}{p_{2}}\right)^{1 / \sigma}(1+q)-1 .
$$


Among the second category of households, the country 1 monopolist in sector $q$ ends up with those characterized by $\gamma \geq \gamma_{1 j}^{\widehat{q}}$, where

$$
\gamma_{1 j}^{\widehat{q}}=\left(\frac{1-m_{1}}{m_{1}}\right)^{\delta / \sigma} \frac{\left(\widetilde{p}_{1}^{q}\right)^{1 / \sigma} p_{2}^{(\sigma-1) / \sigma}(1+q)-p_{2}}{w_{j} \bar{h}_{j} L_{j}+\pi_{j}}, j=1,2 .
$$

Therefore, the effective demand for good $q$ produced in country 1 at price $\widetilde{p}_{1}$, is

$$
\widetilde{D}_{1}^{q}=\sum_{j} \widetilde{D}_{1 j}^{q}
$$

with $\widetilde{D}_{1 j}^{q}=\lambda_{1}\left(1-G_{j}\left(\gamma_{1 j}^{\widetilde{q}}\right)\right) L_{j}+\int_{1-\widetilde{\lambda}_{1}}^{1-\lambda_{1}}\left(1-G_{j}\left(\gamma_{1 j}^{\widehat{q}}\right)\right) L_{j} d m_{1}$.

Let $g_{j}(\gamma)$ be the density of type- $\gamma$ households in country $j$ and $\beta_{j}(\gamma)=$ $g_{j}(\gamma) \gamma /\left(1-G_{j}(\gamma)\right)$. The price elasticity of demand for good $q$ can be written as follows

$$
\begin{aligned}
-\frac{\partial \widetilde{D}_{1}^{q}}{\partial \widetilde{p}_{1}^{q}} \frac{\widetilde{p}_{1}^{q}}{\widetilde{D}_{1}^{q}}= & \sum_{j}\left(\frac{\lambda_{1} \beta_{j}\left(\gamma_{1 j}^{\widetilde{q}}\right)\left(1-G_{j}\left(\gamma_{1 j}^{\widetilde{q}}\right)\right) L_{j}}{\sigma \widetilde{D}_{1}^{q}}\left(1+\frac{1}{\widetilde{q}}\right)\right. \\
& +\int_{1-\widetilde{\lambda}_{1}}^{1-\lambda_{1}} \frac{\beta_{j}\left(\gamma_{1 j}^{\widehat{q}}\right)\left(1-G_{j}\left(\gamma_{1 j}^{\widehat{q}}\right)\right) L_{j}}{\sigma \widetilde{D}_{1}^{q}}\left(1+\frac{1}{\widehat{q}}\right) d m_{1} \\
& \left.+\frac{\widetilde{\lambda}_{1}\left(1-\widetilde{\lambda}_{1}\right)\left(1-G_{j}\left(\gamma_{2 j}^{q}\right)\right) L_{j}}{\delta \widetilde{D}_{1}^{q}}\right) .
\end{aligned}
$$

We define $\beta^{\max }=\max \left(\beta_{j}(\gamma)\right), \gamma^{\min }=\min \left(\gamma_{j}\right)$, and observe that $M_{1} \geq 1$ implies $q \geq \widehat{q} \geq \widetilde{q} \geq \gamma_{1} \widehat{A}_{1} L_{1} / \alpha$. Equation (24) can be shown to be smaller than

$$
\frac{\beta^{\max }}{\sigma}\left(1+\frac{\alpha}{\gamma_{1} \widehat{A}_{1} L_{1}}\right)+\frac{1-\lambda_{1}}{\delta} \frac{\sum_{j}\left(1-G_{j}\left(\gamma_{2 j}^{q}\right)\right) L_{j}}{\sum_{j}\left(1-G_{j}\left(\gamma_{1 j}^{q}\right)\right) L_{j}},
$$

which allows us to rewrite Eq. (23) as

$$
\left(\frac{\beta^{\max }}{\sigma}\left(1+\frac{\alpha}{\gamma_{1} \widehat{A}_{1} L_{1}}\right)+\frac{1-\lambda_{1}}{\delta} \frac{\sum_{j}\left(1-G_{j}\left(\gamma_{2 j}^{q}\right)\right) L_{j}}{\sum_{j}\left(1-G_{j}\left(\gamma_{1 j}^{q}\right)\right) L_{j}}\right)\left(\frac{\alpha-1}{\alpha}\right)<1 .
$$


In order to express Eq. (25) as a function of the set of parameters which govern the world distribution of real income, we need to specify $G_{j}(\gamma)$. We define $G_{j}(\gamma)$ to be the Pareto distribution which has the following useful properties: $\beta_{j}(\gamma)=\beta_{j}, \forall \gamma$, and $\gamma_{j}=\left(\beta_{j}-1\right) /\left(\beta_{j} L_{j}\right)$. First, we can show that

$$
\frac{\sum_{j}\left(1-G_{j}\left(\gamma_{2 j}^{q}\right)\right) L_{j}}{\sum_{j}\left(1-G_{j}\left(\gamma_{1 j}^{q}\right)\right) L_{j}} \leq\left(\frac{1-\lambda_{1}}{\lambda_{1}}\right)^{\delta \beta^{\max }} .
$$

Secondly, given that $\alpha \geq M_{j} \geq 1$, Eq. (15) implies

$$
\frac{1-\lambda_{1}}{\lambda_{1}} \leq\left(\frac{\alpha \widehat{A}_{2} L_{2}}{\widehat{A}_{1} L_{1}}\right)^{\frac{1}{1+\delta}}
$$

Using Eqs. (25), (26), and (27), the following inequality provides a sufficient condition for ruling out price-cutting equilibria:

$$
\left(\frac{\beta^{\max }}{\sigma}\left(1+\frac{\beta_{1} \alpha}{\left(\beta_{1}-1\right) \widehat{A}_{1}}\right)+\frac{1}{\delta} \frac{\left(\frac{\alpha \widehat{A}_{2} L_{2}}{\widehat{A}_{1} L_{1}}\right)^{\frac{1+\delta \beta^{\max }}{1+\delta}}}{1+\left(\frac{\alpha \widehat{A}_{2} L_{2}}{\widehat{A}_{1} L_{1}}\right)^{\frac{1}{1+\delta}}}\right)\left(\frac{\alpha-1}{\alpha}\right)<1 .
$$

As long as Eq. (23) is satisfied, when a firm in country 1 with access to IRS technology in industry $q$ aims to cut the price below $\alpha w_{1} / A_{1}$, it is not able to expand its customer base to such an extent as to compensate the loss in the rate of profit per customer, thus discouraging price-cutting. In our framework, such condition results in Eq. (28). Neither the domestic nor the world income distribution should degenerate around any type- $\gamma$, together with $\sigma$ and $\delta$ being sufficiently above unity, for price-cutting to be ruled out. A similar sufficient condition applies to firms in country 2 with access to IRS technology.

\section{References}

Dalgin, M., Mitra, D., Trindade, V., 2004. Inequality, nonhomothetic preferences, and trade: a gravity approach. NBER Working Paper No. 10800, revised May 2006, King's College.

Dornbusch, R., Fischer, S., Samuelson, P.A., 1977. Comparative advantage, 
trade, and payments in a Ricardian model with a continuum of goods. American Economic Review 67 (5), 823-839.

Ethier, W.J., 1982. Decreasing costs in international trade and Frank Graham's argument for protection. Econometrica 50 (5), 1243-1268.

Foellmi, R., Zweimüller, J., 2006. Income distribution and demand-induced innovations. Review of Economic Studies 73 (4), 941-960.

Francois, J.F., Kaplan, S., 1996. Aggregate demand shifts, income distribution, and the Linder hypothesis. Review of Economics and Statistics 78 (2), 244-250.

Graham, F., 1923. Some aspects of protection further considered. Quarterly Journal of Economics 37 (2), 199-227.

Helpman, E., 1984. Increasing returns, imperfect markets, and trade theory. In Jones, R.W., and Kenen, P.B. (Eds), Handbook of International Economics, vol. 1. Amsterdam: North Holland.

Helpman, E., Krugman, P., 1985. Market Structure and Foreign Trade. Cambridge MA: MIT Press.

Heston, A., Summers, R., Aten, B., 2006. Penn World Table Version 6.2, Center for International Comparisons of Production, Income and Prices at the University of Pennsylvania.

Hirschman, A.O., 1958. The Strategy of Economic Development. New Haven: Yale University Press.

Irwin, D.A., 2008. Infant industry protection. In Durlauf, S.N., and Blume, L.E. (Eds.), The New Palgrave Dictionary of Economics, $2^{\text {nd }}$ Edition. Palgrave Macmillan.

Krugman, P., 1980. Scale economies, product differentiation, and the pattern of trade. American Economic Review 70 (5), 950-959.

Krugman, P., 1995. Development, Geography, and Economic Theory. Cambridge MA: MIT Press.

Lancaster, K., 1979. Variety, Equity, and Efficiency. New York: Columbia University Press.

Matsuyama, K., 1995. Complementarities and cumulative processes in models of monopolistic competition. Journal of Economic Literature XXXIII, 701-729.

Matsuyama, K., 2000. A Ricardian model with a continuum of goods under nonhomothetic preferences: demand complementarities, income distribution, and North-South trade. Journal of Political Economy 108 (6), 1093-1120.

Melitz, M.J., 2005. When and how should infant industries be protected? Journal of International Economics 66 (1), 177-196. 
Mitra, D., Trindade, V., 2005. Inequality and trade. Canadian Journal of Economics 38 (4), 1253-1271.

Mukhopadhaya, P., 2004. World income inequality data base (WIID) review. Journal of Economic Inequality 2, 229-234.

Murphy, K.M., Shleifer, A., Vishny, R., 1989a. Industrialization and the big push. Journal of Political Economy 97 (5), 1003-1026.

Murphy, K.M., Shleifer, A., Vishny, R., 1989b. Income distribution, market size, and industrialization. Quarterly Journal of Economics 104 (3), 537-564. Ray, D., 1998. Development Economics. Princeton University Press.

Rodríguez-Clare, A., 1996. Multinationals, linkages, and economic development. American Economic Review 86 (4), 852-873.

Rosenstein-Rodan, P.M., 1943. Problems of industrialisation of Eastern and South-Eastern Europe. Economic Journal 53 (210/211), 202-211.

Solow, R.M., 2005. Reflections on growth theory. In: Aghion, P., and Durlauf, S.N. (Eds.), Handbook of Economic Growth. Elsevier B.V.

Winters, L.A., Yusuf, S. 2007. Dancing with Giants: China, India, and the Global Economy. The International Bank for Reconstruction and Development.

World Bank Global Economic Prospects, 2007. Managing the Next Wave of Globalization. The International Bank for Reconstruction and Development. 